\title{
Efeito de hidrolisado de peixe sobre o crescimento micelial e controle de Cylindrocladium spathiphylli em espatifilo.
}

\author{
Alexandre Visconti ${ }^{1^{*}}$, Wagner Bettiol ${ }^{2 *}$, Marcelo Augusto Boechat Morandi ${ }^{2}$
}

\begin{abstract}
${ }^{1}$ Empresa de Pesquisa Agropecuária e Extensão Rural de Santa Catarina, EPAGRI, CEP 88034-901, Florianópolis, SC, Brasil, e-mail: visconti@epagri.sc.gov.br; ${ }^{1}$ Universidade Estadual Paulista “Júlio de Mesquita Filho", UNESP/FCA-Botucatu, CEP 18610-307, Botucatu, SP, ${ }^{2}$ Embrapa Meio Ambiente, CP. 69, CEP 13820-000, Jaguariúna, SP, Brasil. *Bolsistas do CNPq. Parte da Dissertação de Mestrado do primeiro autor. Autor para correspondência: Alexandre Visconti (visconti@epagri.sc.gov.br)

Data de chegada: 22/09/2008. Aceito para publicação em: 01/01/2010.
\end{abstract}

\section{RESUMO}

Visconti, A.; Bettiol, W.; Morandi, M.A.B. Efeito de hidrolisado de peixe sobre o crescimento micelial e controle de Cylindrocladium spathiphylli em espatifilo. Summa Phytopathologica, v.36, n.4, p.298-308, 2010.

Hidrolisado de peixe (HP), cama de frango (CF), casca de camarão (CC), esterco bovino (EB), lodo de esgoto (LE) e torta de mamona (TM) foram avaliados quanto ao efeito de seus extratos aquosos, com e sem autoclavagem, sobre o crescimento micelial e a germinação de conídios de Cylindrocladium spathiphylli. O efeito de misturas dos resíduos com o substrato de cultivo e seus compostos voláteis também foram avaliados sobre o crescimento micelial do patógeno. Para avaliar do efeito do HP na supressividade a Cylindrocladium spathiphylli, adicionou-se ao substrato artificialmente infestado o HP nas concentrações de $0,10,20$, 30,40 e $50 \%$ do volume de água necessário para atingir a capacidade de retenção de água do substrato. As misturas foram incubadas por 10 dias e transferidas para vasos contendo uma muda de espatifilo da cultivar Opal por vaso. Nos experimentos in vitro, os extratos aquosos e as misturas de substrato contendo HP apresentaram a maior supressividade ao patógeno. No cultivo de espatifilo, a supressividade ocorreu nas concentrações superiores a $20 \%$ de hidrolisado de peixe.

Palavras-chave adicionais: Cylindrocladium spathiphylli, hidrolisado de peixe, supressividade, matéria orgânica.

\section{ABSTRACT}

Visconti, A.; Bettiol, W.; Morandi, M.A.B. Effect of fish hydrolyzed on mycelial growth and control of Cylindrocladium spathiphylli in Spathiphyllum. Summa Phytopathologica, v.36, n.4, p.298-308, 2010.

Fish hydrolyzed (HP), poultry manure (CF), shrimp skin (CC), cattle manure (EB), sewage sludge (LE) and castorbean presscake (TM) were evaluated for their effect of aqueous extracts with and without autoclaving, on mycelial growth and conidial germination of Cylindrocladium spathiphylli. The effect of mixtures of residues with potting mixes and their volatile compounds were also evaluated on the mycelial growth of the pathogen. To evaluate the effect of HP in the suppressiveness to Cylindrocladium spathiphylli, HP was added in potting mix artificially infested, at concentrations of $0,10,20,30,40$ and $50 \%$ of the volume of water required to reach the water retention capacity of the potting mix. The mixtures were incubated for 10 days and transferred to pots containing one plug of Spathiphyllum Opal per pot. In the experiments in vitro, aqueous extracts and mixtures containing HP showed the highest suppressiveness against the pathogen. In the Spathiphyllum growing, the suppressiveness occurred at concentrations higher than $20 \%$ of fish hidrolyzed.

Keywords: Cylindrocladium spathiphylli, fish hydrolysed, suppressiveness, organic matter.

Cylindrocladium spathiphylli Schoulties, El-Gholl \& Alfieri (teleomorfo: Calonectria spathiphylli El-Gholl, Uschida, Alfenas, Schub \& Alfieri), agente causal da podridão do colo e da raiz de espatifilo (Spathiphyllum wallisi Regel), é o principal patógeno da cultura e ocorre em todos os países onde se cultiva essa ornamental $(8,29)$. A cultura é conduzida basicamente em substratos à base de casca de pinus que são conducentes ao patógeno, acarretando perdas expressivas quando esse se instala no sistema de produção $(8,24)$.

O controle da doença é realizado principalmente com a aplicação de fungicidas à base de tiofanato metílico, iprodione, prochloraz e trifumizole (7) ao longo do ciclo da cultura que é de aproximadamente
18 meses. Porém, estes princípios ativos são efetivos somente quando aplicados em condições de baixa pressão da doença (24). As exigências da sociedade para a redução do uso de agrotóxicos associados aos problemas com resistência aos fungicidas (23) tem induzido a busca por métodos alternativos para o controle da doença (29). Assim, a introdução de agentes de biocontrole e a utilização de substratos desinfestados para o patógeno são estudados, porém, até o momento sem muito sucesso para o patossistema. Dessa forma, uma das alternativas é a utilização de resíduos orgânicos incorporados ao substrato padrão com o objetivo de induzir a supressividade ao patógeno (30). 
Nesse sentido, Termorshuizen et al. (29) analisaram a supressividade de 18 compostos em sete patossistemas obtendo resultados variáveis, significativos de supressão da doença em $54 \%$ dos casos e aumento em 3,3\%. Para C. spathiphylli, os autores verificaram indução de supressividade ao patógeno em três tipos de composto incorporado a substrato padrão, sendo à base de resíduos de poda de jardim sem grama (63,5\%); na mistura contendo $88 \%$ de cavacos de madeira, $2,5 \%$ de esterco e $10 \%$ de argila $(58,9 \%)$; e no composto de cavacos de madeira, resíduos de plantas e esterco de cavalo $(47,4 \%)$. Observaram também, correlação inversa entre a incidência da doença e o $\mathrm{pH}$ do substrato. Para o patossistema $C$. spathiphylli X $S$. wallisi, os substratos com $\mathrm{pH}$ superior a 5,5 apresentaram efeito supressivo ao patógeno. Chase \& Poole (8) verificaram redução na incidência da doença com a elevação do $\mathrm{pH}$ do substrato para 6,5, com calcário dolomítico, durante o inverno e primavera. Entretanto, não verificaram efeito no verão.

Resíduos orgânicos incorporados ao solo ou em misturas com substratos são descritos como potenciais indutores de supressividade a fitopatógenos. Diversos autores descrevem a ação do lodo de esgoto sobre Sclerotium rolfsii (26); esterco líquido de suíno, cama de frango e esterco bovino sobre Verticillium dahliae e Streptomyces scabies (4); de emulsão de peixe sobre Rhizoctonia solani e Pythium aphanidermatum (1) e sobre V. dahliae, Verticillium albo-atrum e $S$. scabies $(2,20)$; da cama de aves, esterco suíno, torta de mamona e lodo de esgoto (5) e casca de camarão, hidrolisado de peixe e quitosana
(25) em F. oxysporum f. sp. chrysanthemi.

O presente trabalho teve por objetivos avaliar o efeito de fontes de matéria orgânica sobre o crescimento micelial e o controle de $C$. spathiphylli para colaborar no desenvolvimento de substratos supressivos ao patógeno.

\section{MATERIAL E MÉTODOS}

Hidrolisado de peixe (HP), casca de camarão moida (CC), lodo de esgoto (LE), torta de mamona (TM), cama de frango compostada (CF) e esterco bovino compostado (EB) (Tabela 1) foram avaliados quanto ao efeito sobre o crescimento micelial de $C$. spathiphylli (isolado CCMA552 depositado na coleção da Embrapa Meio Ambiente, obtido de plantas de espatifílo infectadas com o patógeno, oriundas do município de Holambra-SP).

Efeito dos extratos aquosos de matéria orgânica (EAMOs) no crescimento micelial de $\boldsymbol{C}$. spathiphylli. Os EAMOs foram obtidos misturando-se cada material orgânico com água destilada na proporção de 1:3 (peso/volume), homogeneizando a mistura e mantendo-a em repouso por uma hora. Duas formas de extração foram realizadas, sem e com autoclavagem da mistura a $120^{\circ} \mathrm{C} \mathrm{e} 1$ atm por 1 hora. Após essa fase, a parte líquida foi separada da sólida com auxílio de bomba de vácuo, seguida de resfriamento para armazenamento em geladeira a 3

Tabela 1. Atributos químicos dos materiais orgânicos testados na inibição do crescimento micelial de Cylindrocladium spathiphylli.

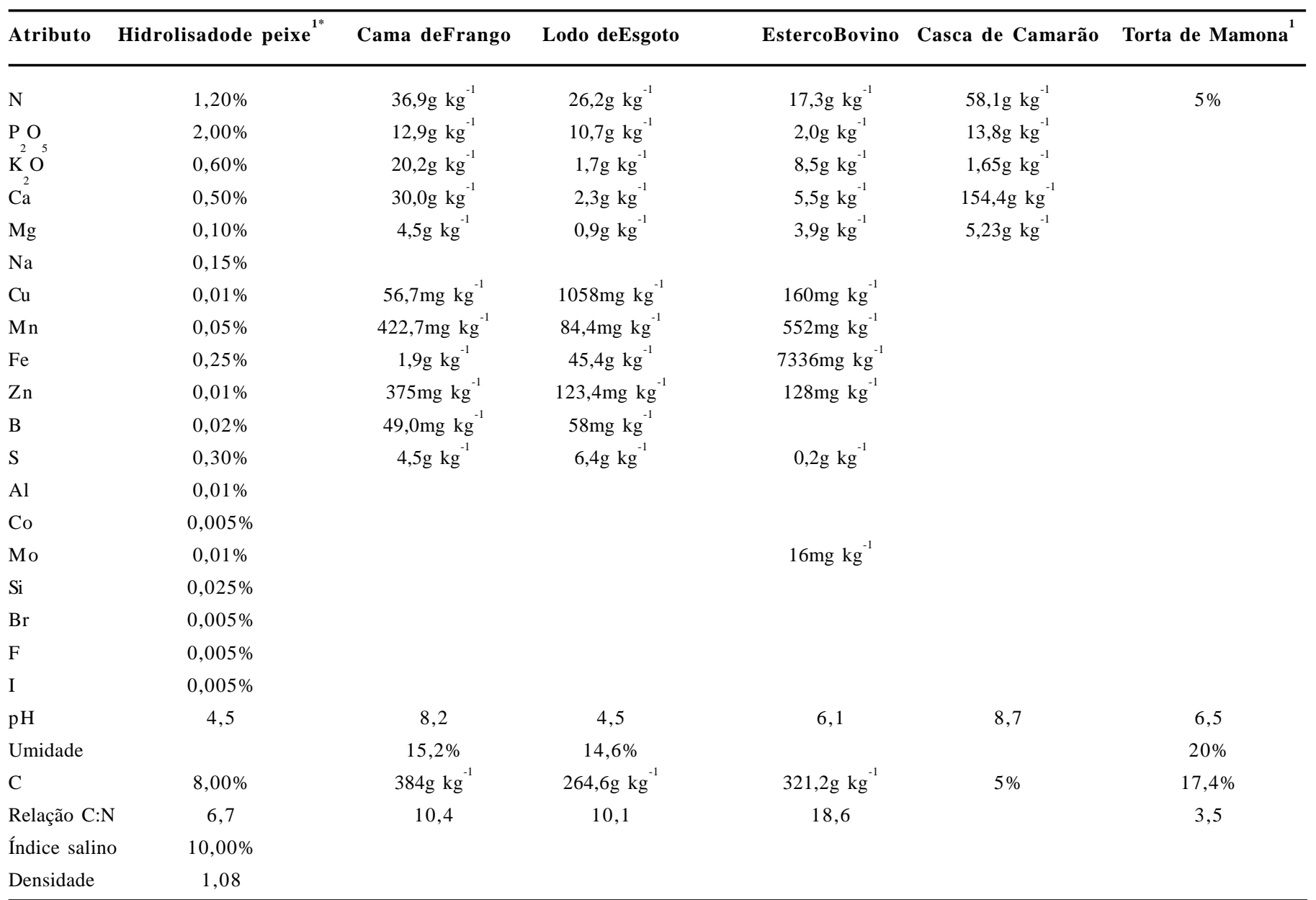

${ }^{1}$ Dados fornecidos pela indústria. *Ácidos graxos voláteis (mM) presentes em hidrolisado no peixe, segundo Bettiol et al. (6): Glicolato: 768,1; Formato: 20,4; Acetato: 197,9; Propionato: 45,0; $n$-Butirato: 46,4; iso-Butirato: 9,0; iso-Valerato: 4,6; Total AGV: 1091,4. 
${ }^{\circ} \mathrm{C} \pm 2$. Os EAMOs foram incorporados nas concentrações de 0,5 , $10,15,20,25$ e $30 \%$ (v/v) ao meio Batata-Dextrose-Ágar (BDA). Após a correção do $\mathrm{pH}$ a $6,0 \mathrm{com} \mathrm{NaOH}$, os meios foram autoclavados a $120{ }^{\circ} \mathrm{C}$ e $1 \mathrm{~atm}$ por 20 minutos e, em seguida, vertidos em placas de Petri de $9 \mathrm{~cm}$ de diâmetro. Após 24 h, foi transferido, para o centro de cada placa, um disco de BDA de $8 \mathrm{~mm}$ de diâmetro contendo micélio do patógeno em pleno desenvolvimento. As placas foram mantidas em sala de incubação a $25^{\circ} \mathrm{C} \pm 2$ e avaliados diariamente os diâmetros perpendiculares da colônia por oito dias. A área abaixo da curva de crescimento micelial (AACCM) de C. spathiphylli foi determinada para cada tratamento. $\mathrm{O}$ experimento foi conduzido em delineamento inteiramente casualizado com cinco repetições.

Efeito de extratos aquosos de matéria orgânica na germinação de conídios de $C$. spathiphylli. Sobre lâminas de vidro esterilizadas, foi depositado $100 \mu \mathrm{L}$ de uma suspensão contendo $10^{6}$ conídios $\mathrm{mL}$ ${ }^{1}$ do patógeno obtida de colônias desenvolvidas em BDA. Em seguida, $100 \mu \mathrm{L}$ de suspensão contendo EAMOs nas concentrações de 0,1 , $10,100,1000,10.000,100.000$ e 1.000 .000 ppm foram misturados à suspensão do patógeno. Os EAMOs foram previamente esterilizados utilizando-se centrifugação a $13.000 \mathrm{rpm}$ por 15 minutos seguido de passagem em filtro Milipore $0,22 \mu \mathrm{M}$. As lâminas foram mantidas em câmara úmida a $25^{\circ} \mathrm{C} \pm 2$ e ausência de luz. A contagem de conídios germinados foi iniciada quando $50 \%$ dos conídios na testemunha estavam germinados, isto é após aproximadamente 2 horas. O delineamento experimental foi inteiramente casualizado com 10 repetições ( 1 gota $=1$ repetição). A contagem de conídios foi realizada em cinco campos de cada gota em microscópio óptico em 100 aumentos.

Efeito dos materiais orgânicos adicionados ao substrato padrão sobre o crescimento micelial de $C$. spathiphylli. Ao substrato padrão Multiplant ${ }^{\circledR}$ (Terra do Paraíso, Holambra-SP) - $(60 \%$ de composto de casca de pinus, $15 \%$ de vermiculita e $25 \%$ de húmus e terra vegetal, pH 5,5, CE $0,6 \mu \mathrm{S} \mathrm{cm}^{-1}$ ) - utilizado para a produção de Spathiphillum, foram incorporados os materiais orgânicos nas concentrações de $0,5,10,15,20$ e $25 \%$ (v/v), sendo as misturas não autoclavadas e autoclavadas a $120^{\circ} \mathrm{C}$ e 1 atm por 20 minutos. Em seguida, essas misturas foram colocadas no fundo de placas de Petri e após uniformização receberam uma camada de Ágar-Água (AA) fundente na superfície. Após $24 \mathrm{~h}$ foi transferido para o centro de cada placa um disco de $8 \mathrm{~mm}$ de BDA contendo micélio do patógeno em pleno desenvolvimento e, posteriormente, selada com filme de polietileno. As placas foram mantidas em sala de incubação a $25^{\circ} \mathrm{C} \pm$ 2 e diariamente foi avaliado o crescimento micelial por meio da média dos diâmetros perpendiculares da colônia. A partir dos dados do crescimento micelial médio diário, no período de sete dias, foi calculada a área abaixo da curva de crescimento micelial (AACCM). O experimento foi conduzido em delineamento inteiramente casualizado com três repetições $(1$ placa $=1$ repetição $)$.

Efeito de compostos voláteis dos materiais orgânicos sobre o crescimento micelial de $\boldsymbol{C}$. spathiphylli. O efeito dos metabólitos voláteis foi avaliado utilizando a metodologia de Dick \& Hutchinson (13) modificada. Para tanto, foi adicionada uma camada de $1 \mathrm{~mm}$ das misturas de substrato padrão de cultivo e os materiais orgânicos nas concentrações de $0,5,10,15,20$ e $25 \%$ (v/v) ao fundo de placas de Petri. Tampas de placas de Petri de igual diâmetro contendo meio BDA com um disco de BDA de $8 \mathrm{~mm}$ de diâmetro com o micélio do patógeno foram sobrepostas e vedadas com parafilme. As placas foram mantidas a $25^{\circ} \mathrm{C} \pm 2$, o crescimento micelial foi avaliado diariamente pela média dos diâmetros perpendiculares das colônias e calculada a AACCM. O delineamento experimental foi inteiramente casualizado com cinco repetições $(1$ placa $=1$ repetição $)$.
Efeito do hidrolisado de peixe, adicionado ao substrato de cultivo artificialmente infestado, no controle de $\boldsymbol{C}$. spathiphylli. Para esse estudo foi utilizado o HP, pois foi a matéria orgânica que apresentou os melhores resultados in vitro. $\mathrm{O}$ substrato padrão para o cultivo de Spathiphillum foi infestado com $10^{8}$ conídios $\mathrm{mL}^{-1}$ do patógeno, três dias antes da aplicação do HP. Ao substrato infestado, acondicionado em sacos plásticos negros, adicionou-se hidrolisado de peixe nas concentrações de $0,10,20,30,40$ e 50\% do volume de água necessário para atingir a capacidade de retenção de água do substrato. As misturas foram incubadas por 10 dias e transferidas para vasos plásticos de $300 \mathrm{~mL}$, seguido do plantio de uma muda de espatifilo da cultivar Opal por vaso. Os vasos foram mantidos sob cultivo protegido com cobertura branca fosca e irrigação por aspersão. A partir de 30 dias do plantio as plantas foram adubadas semanalmente com 4 e $6 \mathrm{~g}$ vaso $^{-1}$ de $\mathrm{N}$ (uréia) e $\mathrm{K}\left(\mathrm{KNO}_{3}\right)$, respectivamente. No dia do plantio, foram coletadas amostras dos substratos para a determinação do carbono da biomassa microbiana (CBM), da atividade microbiana do substrato por meio da hidrólise do diacetato de fluoresceína (FDA) e da respiração do substrato. As frações nitrogenadas dos substratos [amônio $\left(\mathrm{N}-\mathrm{NH}_{4}\right)$, amônia $\left(\mathrm{N}-\mathrm{NH}_{3}\right)$, nitrato $\left(\mathrm{N}-\mathrm{NO}_{3}\right)$ e nitrito $(\mathrm{N}-$ $\mathrm{NO}_{2}$ )] foram determinadas no momento do plantio e o $\mathrm{pH}$ e a condutividade elétrica (CE) foram determinados no plantio e ao final do experimento. A severidade da doença foi avaliada semanalmente até aos 182 dias após o plantio utilizando a escala de notas: 1 - planta sadia, 2 - planta murcha, 3 - planta morta. Com os resultados foram calculadas as áreas abaixo da curva de progresso da severidade (AACPS), as curvas de regressão linear e a incidência da doença (ID) em relação a testemunha. O delineamento experimental foi o de blocos ao acaso, composto por três blocos e cinco repetições $(1$ repetição $=$ 1 vaso com uma planta).

Análise estatística. Os resultados dos experimentos foram submetidos à análise de variância e a separação de médias foi realizada pelo teste de Scott-Knott a 5\% utilizando o software SISVAR 5.0 e as regressões no Sigma Plot 11.0.

\section{RESULTADOS}

Efeito dos extratos aquosos de matéria orgânica no crescimento micelial de $\boldsymbol{C}$. spathiphylli. Os EAMOs não autoclavados de hidrolisado de peixe de 10 a $30 \%$, cama de frango de 15 a $30 \%$ e casca de camarão de 5 a $15 \%$ reduziram o crescimento micelial do patógeno. Porém, o efeito foi dependente das concentrações dos extratos aquosos. O HP a $25 \%$ apresentou a maior inibição $(81,5 \%)$ em relação à testemunha (Tabela 2). Os extratos aquosos da torta de mamona, do lodo de esgoto e do esterco bovino estimularam o crescimento micelial do patógeno (dados não apresentados). Os extratos aquosos autoclavados foram menos eficientes do que os não autoclavados (Tabela 2). Para os extratos autoclavados, as concentrações de HP de 10 a 30\%, CF a 5, 20, 25 e $30 \%$ e CC a 10 e $20 \%$ apresentaram inibição do crescimento micelial semelhante, sendo o máximo de 28,4\% em relação à testemunha (Tabela 2 ).

Efeito de extratos aquosos de matéria orgânica na germinação de conídios de $\boldsymbol{C}$. spathiphylli. Os extratos aquosos estimularam a germinação de conídios de $C$. spathiphylli, com exceção dos extratos de $\mathrm{HP}$ e CF na concentração de $1.000 .000 \mathrm{ppm}$, que reduziu a porcentagem de germinação de 44,3 para $6,4 \%$ e de 51,5 para $13,0 \%$, respectivamente, em relação a testemunha (Tabela 3 ).

Efeito dos materiais orgânicos adicionados ao substrato padrão sobre o crescimento micelial de $\boldsymbol{C}$. spathiphylli. As concentrações 
Tabela 2. Efeito dos extratos aquosos de matéria orgânica (EAMOs) autoclavados e não autoclavados sobre a área abaixo da curva de crescimento micelial (AACCM) de Cylindrocladium spatiphylli adicionados ao meio Batata-Dextrose-Ágar.

\begin{tabular}{|c|c|c|c|c|c|}
\hline \multirow{2}{*}{ Resíduo } & \multirow{2}{*}{ Concentração (\%) } & \multicolumn{2}{|c|}{ EAMOs Autoclavado } & \multicolumn{2}{|c|}{ EAMOs Não Autoclavado } \\
\hline & & AACCM & $\mathrm{IICM}(\%)^{*}$ & AACCM & $\operatorname{IICM}(\%)^{*}$ \\
\hline \multirow{7}{*}{$\begin{array}{c}\text { Hidrolisado } \\
\text { de peixe }\end{array}$} & 0 & $186,2^{1} \pm 8,5^{2} \mathrm{aC}$ & - & $189,5 \pm 4,2 \mathrm{aE}$ & - \\
\hline & 5 & $163,9 \pm 6,5 \mathrm{aB}$ & $10,9 \pm 6,5$ & $188,2 \pm 4,5 \mathrm{bE}$ & $0,4 \pm 3,3$ \\
\hline & 10 & $140,0 \pm 16,6 \mathrm{aA}$ & $23,9 \pm 10,4$ & $159,6 \pm 4,4 \mathrm{aD}$ & $15,4 \pm 4,3$ \\
\hline & 15 & $133,7 \pm 8,7 \mathrm{aA}$ & $28,4 \pm 2,3$ & $145,3 \pm 8,3 \mathrm{aC}$ & $23,2 \pm 4,4$ \\
\hline & 20 & $147,5 \pm 4,2 \mathrm{bA}$ & $20,5 \pm 2,2$ & $125,9 \pm 4,5 \mathrm{aB}$ & $33,3 \pm 3,3$ \\
\hline & 25 & $153,84,7 \mathrm{bA}$ & $17,2 \pm 1,4$ & $34,3 \pm 9,4 \mathrm{aA}$ & $81,5 \pm 5,6$ \\
\hline & 30 & $138,7 \pm 2,8 \mathrm{bA}$ & $24,8 \pm 4,4$ & $115,6 \pm 9,3 \mathrm{aB}$ & $38,9 \pm 4,9$ \\
\hline \multirow{7}{*}{$\begin{array}{l}\text { Cama de } \\
\text { frango }\end{array}$} & 0 & $162,8 \pm 7,2 \mathrm{aB}$ & - & $148,8 \pm 6,8 \mathrm{aB}$ & - \\
\hline & 5 & $148,9 \pm 8,7 \mathrm{aA}$ & $8,1 \pm 5,4$ & $149,9 \pm 19,0 \mathrm{aB}$ & $0,1 \pm 12,7$ \\
\hline & 10 & $164,5 \pm 3,9 \mathrm{bB}$ & 0 & $143,7 \pm 6,5 \mathrm{aB}$ & $2,0 \pm 8,5$ \\
\hline & 15 & $168,0 \pm 2,8 \mathrm{bB}$ & 0 & $129,2 \pm 5,6 \mathrm{aA}$ & $12,6 \pm 5,0$ \\
\hline & 20 & $142,2 \pm 3,2 \mathrm{aA}$ & $11,9 \pm 4,7$ & $123,1 \pm 5,8 \mathrm{aA}$ & $16,5 \pm 6,2$ \\
\hline & 25 & $127,7 \pm 12,1 \mathrm{aA}$ & $21,1 \pm 7,6$ & $122,8 \pm 7,0 \mathrm{aA}$ & $17,3 \pm 4,5$ \\
\hline & 30 & $136,2 \pm 7,0 \mathrm{aA}$ & $15,3 \pm 6,9$ & $121,5 \pm 5,8 \mathrm{aA}$ & $18,1 \pm 4,0$ \\
\hline \multirow{7}{*}{$\begin{array}{l}\text { Casca de } \\
\text { camarão }\end{array}$} & 0 & $140,3 \pm 3,5 \mathrm{aA}$ & - & $216,1 \pm 4,6 \mathrm{bB}$ & - \\
\hline & 5 & $157,4 \pm 7,5 \mathrm{aB}$ & 0 & $196,5 \pm 4,9 \mathrm{bA}$ & $9,0 \pm 2,8$ \\
\hline & 10 & $131,1 \pm 3,3 \mathrm{aA}$ & $6,5 \pm 1,9$ & $194,0 \pm 5,4 \mathrm{bA}$ & $10,1 \pm 2,6$ \\
\hline & 15 & $166,9 \pm 5,3 \mathrm{aB}$ & 0 & $179,8 \pm 3,9 \mathrm{aA}$ & $16,5 \pm 3,3$ \\
\hline & 20 & $138,7 \pm 4,1 \mathrm{aA}$ & $1,0 \pm 2,8$ & $200,7 \pm 1,5 \mathrm{bB}$ & $7,0 \pm 1,3$ \\
\hline & 25 & $148,7 \pm 4,3 \mathrm{aB}$ & 0 & $206,8 \pm 2,0 \mathrm{bB}$ & $4,1 \pm 2,5$ \\
\hline & 30 & $151,9 \pm 7,4 \mathrm{aB}$ & 0 & $204,0 \pm 2,1 \mathrm{bB}$ & $5,5 \pm 1,4$ \\
\hline$\overline{\mathrm{CV}(\%)}$ & & \multicolumn{2}{|c|}{10,61} & \multicolumn{2}{|c|}{9,93} \\
\hline
\end{tabular}

1-Média de 10 repetições; 2- Erro padrão da amostra. *IICM - Índice de inibição do crescimento micelial. Médias seguidas da mesma letra minúscula e maiúscula não diferem estatisticamente entre si na linha e na coluna, respectivamente, pelo teste de Scott-Knott a 5\%.

Tabela 3. Efeito de suspensões aquosas contendo hidrolisado de peixe (HP), cama de frango (CF), torta de mamona (TM), lodo de esgoto (LE), casca de camarão (CC) e esterco bovino (EB) sobre a porcentagem de germinação de conídios de Cylindrocladium spatiphylli.

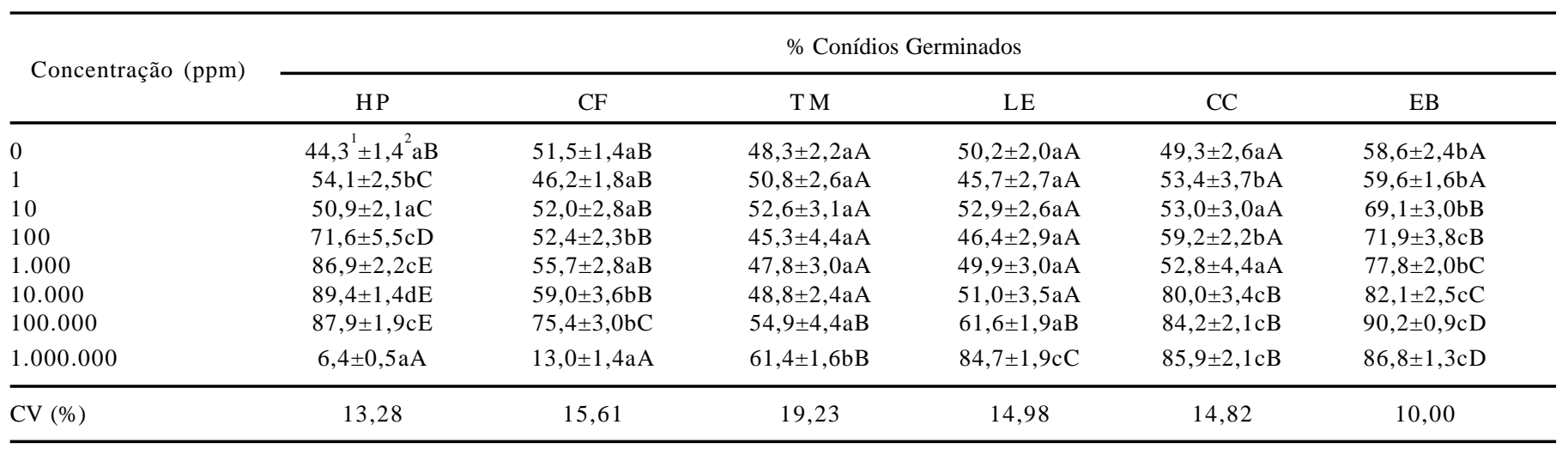

1-Média de 25 repetições; 2- Erro padrão da amostra. Médias seguidas da mesma letra minúscula e maiúscula não diferem estatisticamente entre si na linha e na coluna, respectivamente, pelo teste de Scott-Knott a 5\%.

de 15,20 e $25 \%$ (v/v) de HP, 20 e $25 \%$ de $\mathrm{CF}$ e CC, e 15 e $25 \%$ de TM, quando incorporados ao substrato e sem autoclavagem, suprimiram o crescimento micelial do fungo (Tabela 4). Nas misturas autoclavadas a inibição do crescimento micelial foi inferior às não autoclavadas, exceto para as misturas contendo HP a 10, 15, 20 e $25 \%$ que inibiram o crescimento em $100 \%$ (Tabela 4 ). Semelhante aos extratos aquosos, as misturas contendo EB e LE foram conducentes ao patógeno (dados não apresentados).
Efeito de compostos voláteis dos materiais orgânicos sobre o crescimento micelial de $\boldsymbol{C}$. spathiphylli. Metabólitos voláteis liberados das misturas com HP, CF, TM e CC apresentaram efeito inibitório sobre o crescimento micelial de C. spathiphylli. Para o HP a inibição do crescimento micelial foi diretamente proporcional à concentração aplicada, inibindo completamente o crescimento a 20 e $25 \%$ (Tabela 5). 
Tabela 4. Efeito de substratos autoclavados e não autoclavados contendo hidrolisado de peixe (HP), cama de frango (CF), torta de mamona (TM) e casca de camarão (CC) sobre a área abaixo da curva de crescimento micelial (AACCM) de Cylindrocladium spathiphylli.

\begin{tabular}{|c|c|c|c|c|c|}
\hline \multirow[t]{2}{*}{ Resíduo } & \multirow[t]{2}{*}{ Concentração (\%) } & \multicolumn{2}{|c|}{ Substrato Autoclavado } & \multicolumn{2}{|c|}{ Substrato Não Autoclavado } \\
\hline & & $\mathrm{AACCM}^{*}$ & $\operatorname{IICM}(\%)^{* *}$ & $\mathrm{AACCM}^{*}$ & $\operatorname{IICM}(\%)^{* *}$ \\
\hline \multirow{3}{*}{ HP } & 0 & $14,2^{1} \pm 2,8^{2} \mathrm{bC}$ & - & $12,2 \pm 2,5 \mathrm{aB}$ & - \\
\hline & 10 & $0,7 \pm 0,0 \mathrm{aA}$ & $100,0 \pm 0,0$ & $11,9 \pm 11,5 \mathrm{bB}$ & $5,0 \pm 2,4$ \\
\hline & 15 & $0,7 \pm 0,0 \mathrm{aA}$ & $100,0 \pm 0,0$ & $0,7 \pm 0,0 \mathrm{aA}$ & $100,0 \pm 0,0$ \\
\hline \multirow{5}{*}{$\mathrm{CF}$} & 0 & $14,2 \pm 2,8 \mathrm{bA}$ & - & $12,2 \pm 2,5 \mathrm{aC}$ & - \\
\hline & 5 & $14,5 \pm 4,1 \mathrm{bA}$ & 0 & $12,5 \pm 3,9 \mathrm{aC}$ & 0 \\
\hline & 10 & $15,0 \pm 2,9 \mathrm{bA}$ & 0 & $11,9 \pm 3,9 \mathrm{aC}$ & $4,2 \pm 1,1$ \\
\hline & 15 & $15,0 \pm 1,6 \mathrm{bA}$ & 0 & $8,5 \pm 41,1 \mathrm{aB}$ & $41,3 \pm 28,7$ \\
\hline & 20 & $14,9 \pm 2,9 \mathrm{bA}$ & 0 & $6,7 \pm 19,1 \mathrm{aA}$ & $67,2 \pm 12,3$ \\
\hline \multirow{5}{*}{$\mathrm{T} \mathrm{M}$} & 10 & $14,1 \pm 2,1 \mathrm{bA}$ & $1,6 \pm 0,4$ & $5,5 \pm 0,2 \mathrm{aC}$ & $80,8 \pm 0,3$ \\
\hline & 15 & $14,0 \pm 3,6 \mathrm{bA}$ & $2,5 \pm 1,6$ & $0,7 \pm 0,0 \mathrm{aA}$ & $100 \pm 0,0$ \\
\hline & 20 & $13,6 \pm 2,9 \mathrm{bA}$ & $8,6 \pm 1,0$ & $2,7 \pm 0,9 \mathrm{aB}$ & $95,3 \pm 0,6$ \\
\hline & 25 & $13,6 \pm 3,7 \mathrm{aA}$ & $8,2 \pm 2,4$ & $0,7 \pm 0,0 \mathrm{aA}$ & $100,0 \pm 0,0$ \\
\hline & 0 & $14,2 \pm 2,8 \mathrm{bA}$ & - & $12,2 \pm 2,5 \mathrm{aD}$ & - \\
\hline \multirow{4}{*}{$\mathrm{CC}$} & 5 & $14,4 \pm 5,8 \mathrm{bA}$ & 0 & $10,6 \pm 6,2 \mathrm{aC}$ & $23,5 \pm 5,2$ \\
\hline & 10 & $14,3 \pm 0,3 \mathrm{bA}$ & 0 & $9,2 \pm 0,0 \mathrm{aC}$ & $42,1 \pm 1,0$ \\
\hline & 15 & $14,3 \pm 4,8 \mathrm{bA}$ & 0 & $3,5 \pm 9,0 \mathrm{aB}$ & $89,2 \pm 6,3$ \\
\hline & 20 & $12,8 \pm 6,1 \mathrm{bA}$ & $19,2 \pm 3,4$ & $0,7 \pm 0,0 \mathrm{aA}$ & $100,0 \pm 0,0$ \\
\hline
\end{tabular}

1-Média de 6 repetições; 2- Erro padrão da amostra. *Para análise estatística os dados foram transformados em $\sqrt{ }$ x+0,5. **IICM - Índice de inibição do crescimento micelial. Médias seguidas da mesma letra minúscula e maiúscula não diferem estatisticamente entre si na linha e coluna respectivamente, pelo teste de Scott-Knott a 5\%.

Tabela 5. Efeito de metabólitos voláteis de misturas de hidrolisado de peixe (HP), cama de frango (CF), torta de mamona (TM) e casca de camarão (CC), adicionados ao substrato padrão de cultivo de Spathiphyllum, sobre a área abaixo da curva de crescimento micelial (AACCM) de Cylindrocladium spathiphylli.

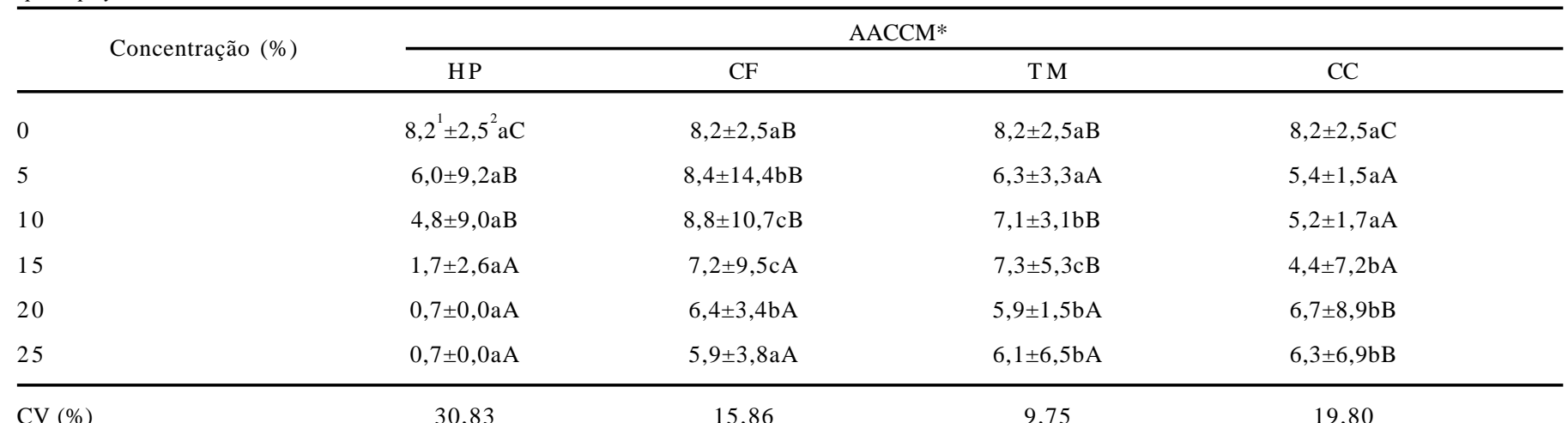

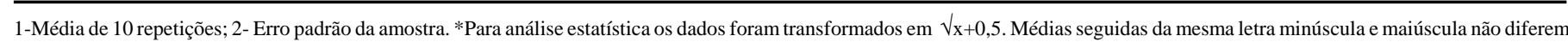
estatisticamente entre si na linha e coluna respectivamente, pelo teste de Scott-Knott a 5\%. 


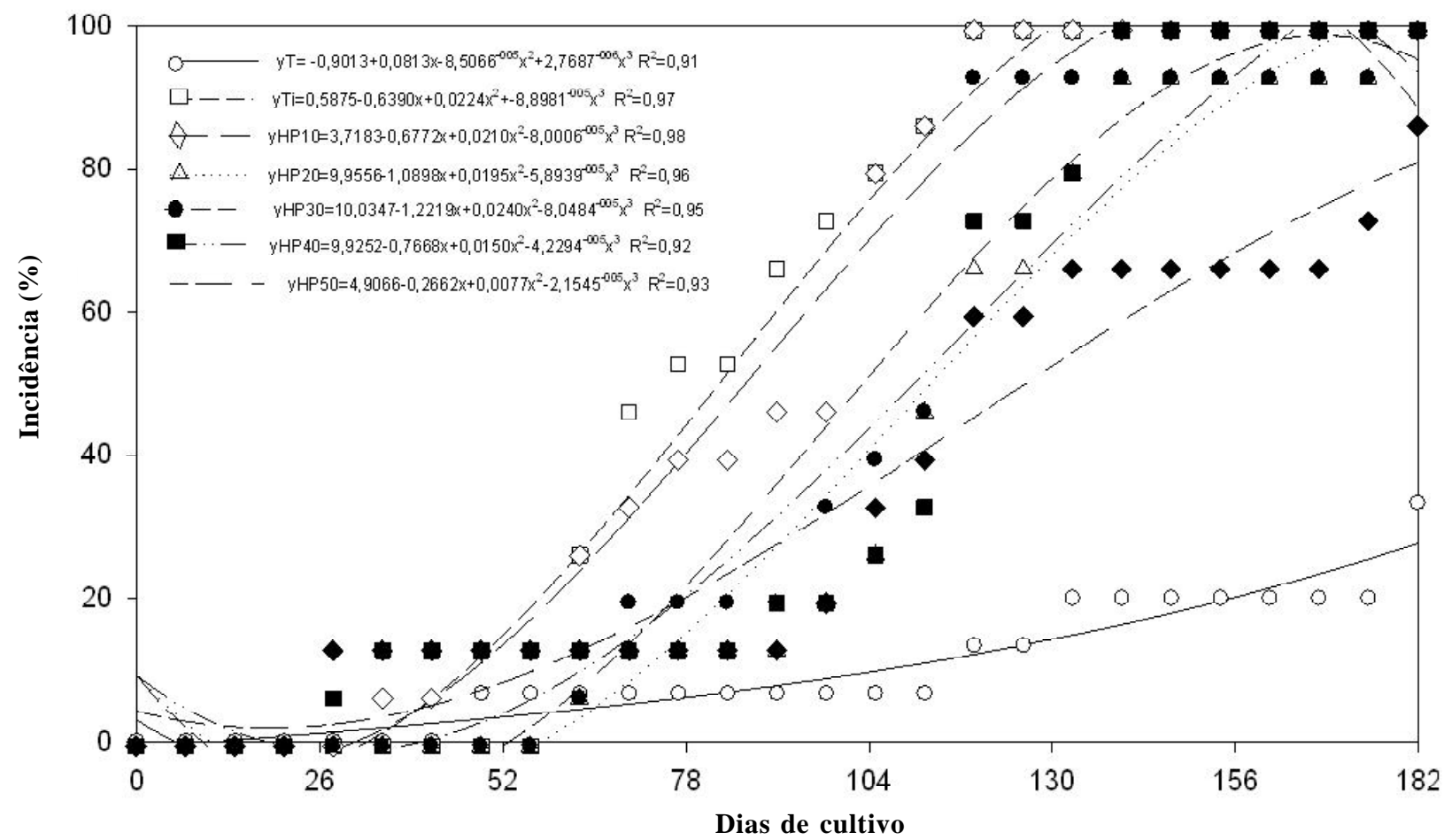

Figura 1. Incidência de Cylindrocladium spatiphylli em plantas de espatifilo no período de 182 dias de plantio, cultivados em misturas de hidrolisado de peixe (HP) adicionado ao substrato padrão de cultivo nas concentrações de 0 ( $\mathrm{T}$ e Ti), 10, 20,30, 40 e $50 \%$ do volume necessário para atingir a capacidade de retenção de água do substrato.

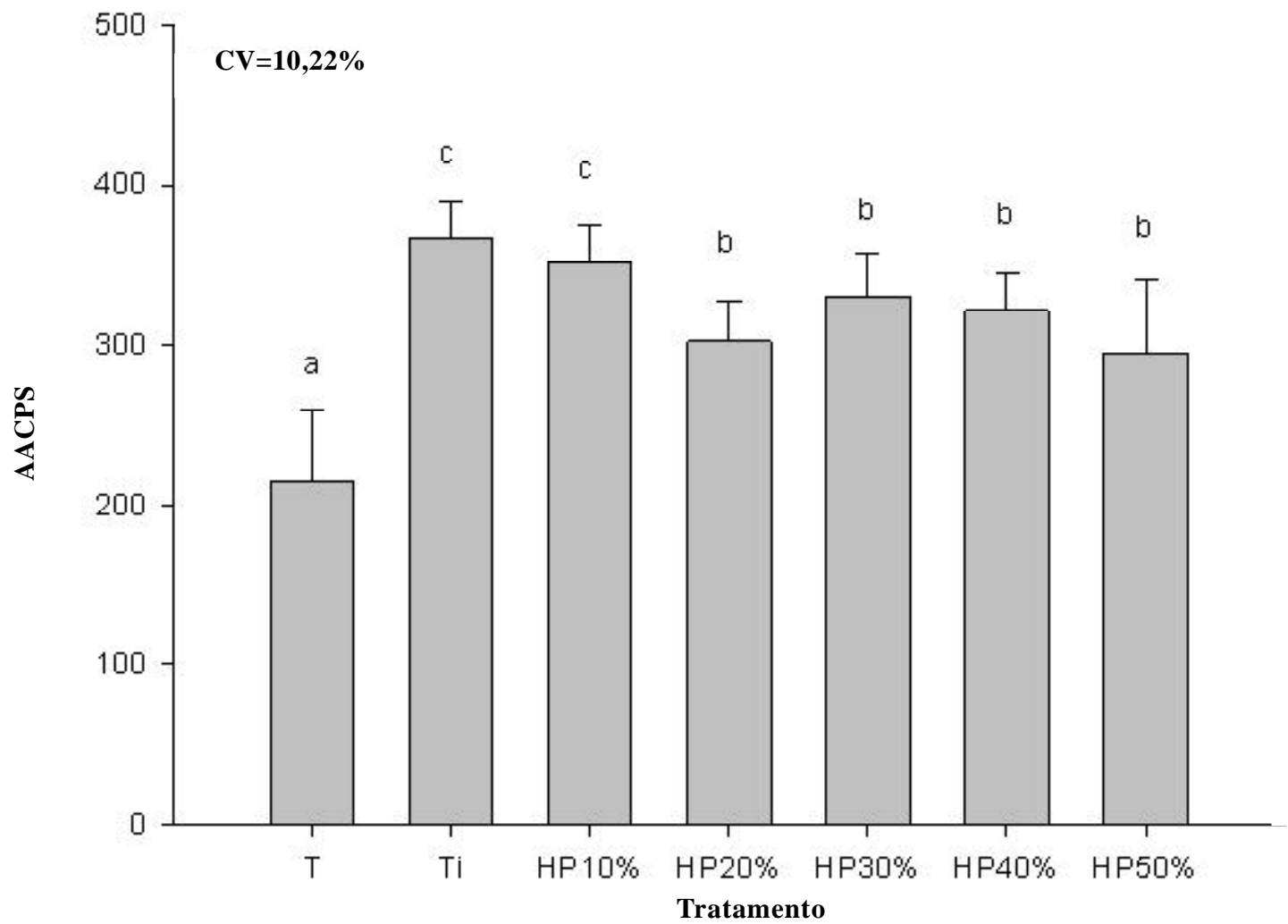

Figura 2. Efeito do hidrolisado de peixe (HP) sobre a área abaixo da curva de progresso da severidade (AACPS) de Cylindrocladium spathiphylli em 182 dias de cultivo de espatifilo. Médias seguidas de mesma letra não diferem estatisticamente entre si a pelo teste de Scott-Knott a $5 \%$. T = testemunha absoluta, $\mathrm{Ti}=$ testemunha inoculada, $\mathrm{HP}=$ hidrolisado de peixe. 

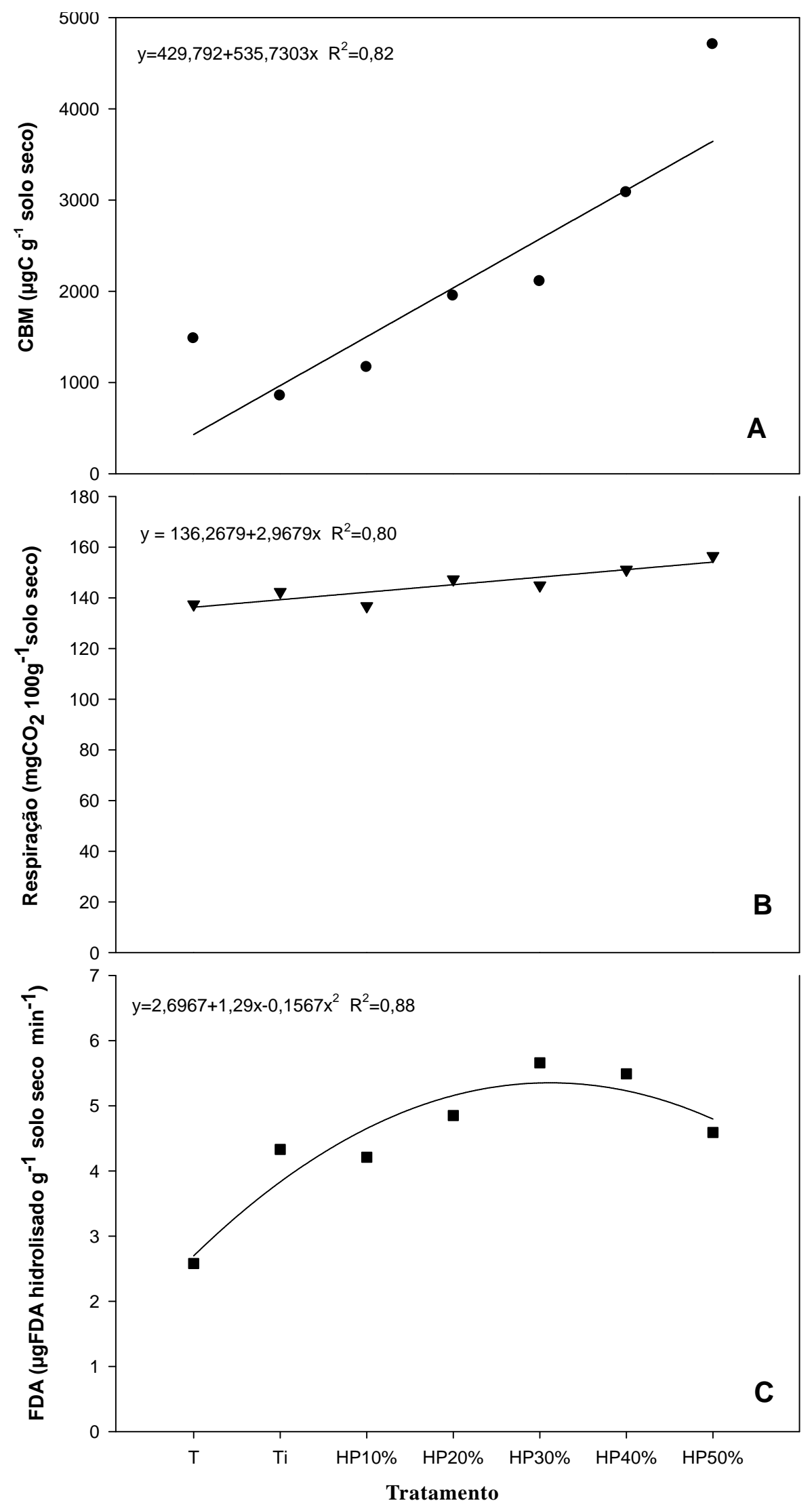

Figura 3. Atividade microbiana determinada pelo: $A=$ carbono da biomassa microbiana $(\mathrm{CBM}), \mathrm{B}=$ respiração do substrato e $\mathrm{C}=$ diacetato de fluoresceína (FDA), de substratos tratados com 0, 10, 203040 e 50\% de hidrolisado de peixe (HP) do volume necessário para atingir a capacidade de retenção de água do substrato. $\mathrm{T}=$ testemunha absoluta, $\mathrm{Ti}=$ testemunha inoculada, $\mathrm{HP}=$ hidrolisado de peixe. 


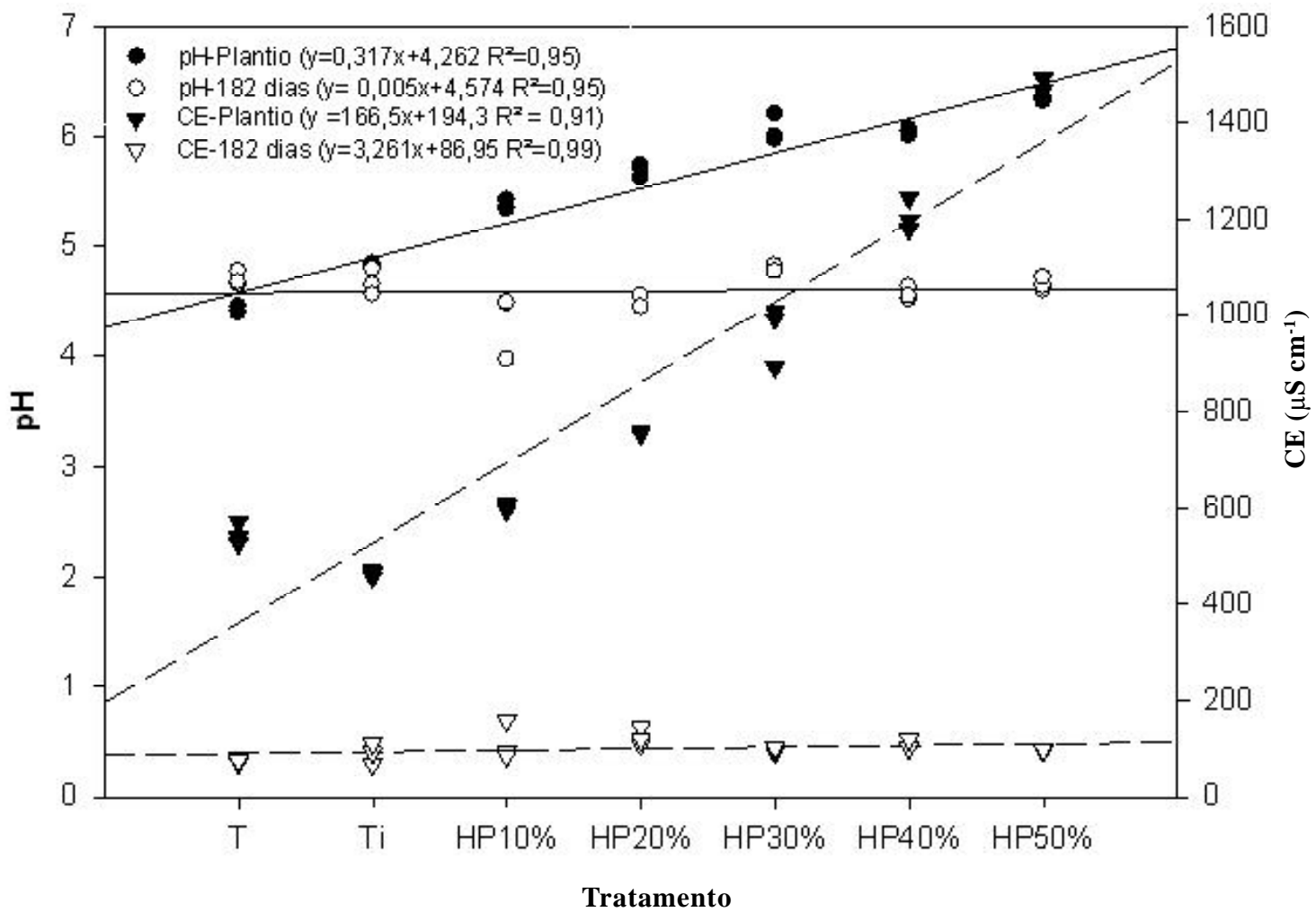

Figura 4. Condutividade elétrica e pH do substrato à base de casca de pinus enriquecido com hidrolisado de peixe (HP) nas concentrações de 0 , 10, 20, 30, 40 e $50 \%$ do volume necessário para atingir a capacidade de retenção de água, no plantio e aos 182 dias de cultivo de espatifilo. $\mathrm{T}=$ testemunha absoluta, $\mathrm{Ti}=$ testemunha inoculada, $\mathrm{HP}=$ hidrolisado de peixe.

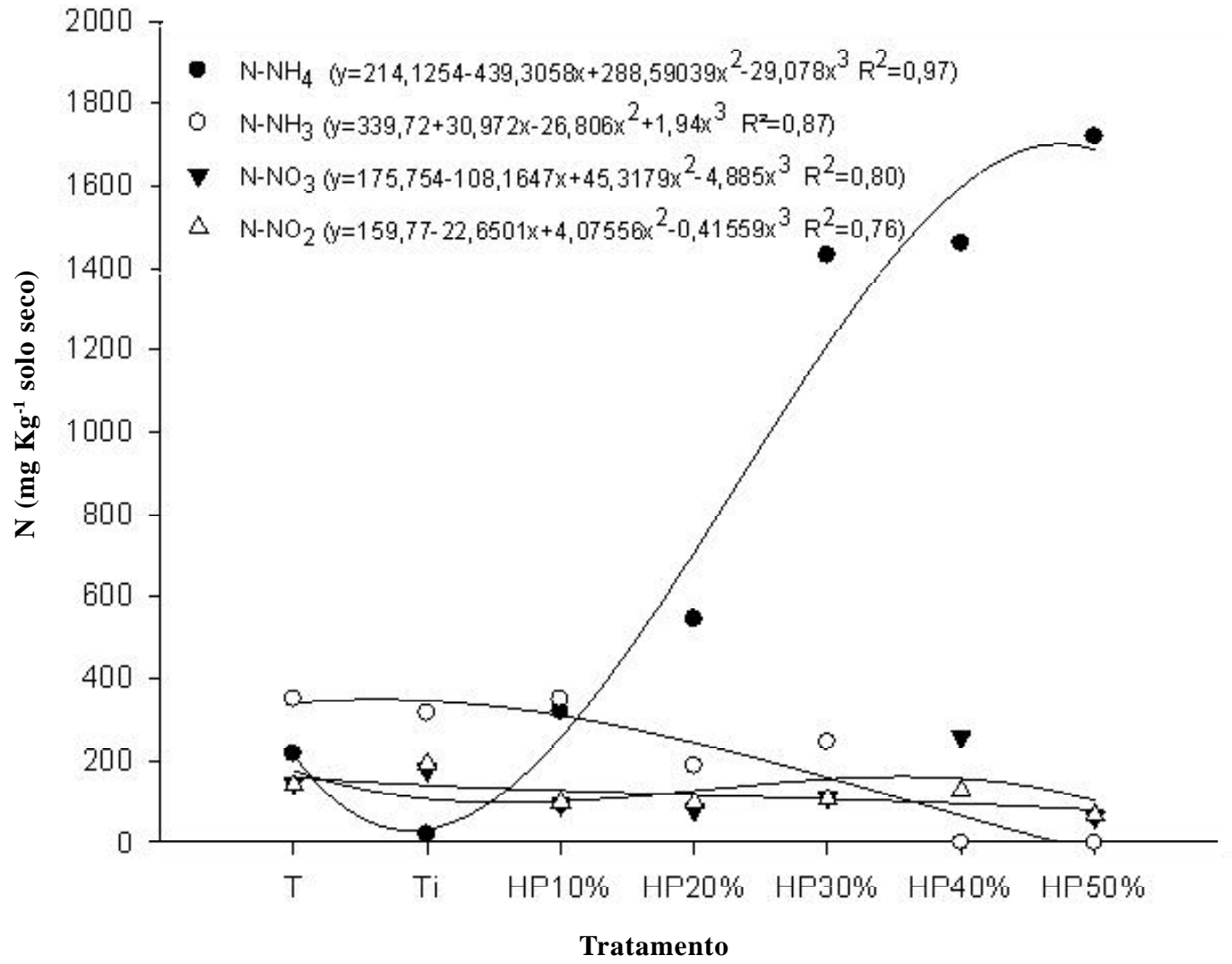

Figura 5. Concentrações de amônio $(\mathrm{N}-\mathrm{NH})$, amônia $(\mathrm{N}-\mathrm{NH})$, nitrato $(\mathrm{N}-\mathrm{NO})$ e nitrito $(\mathrm{N}-\mathrm{NO})$ presentes no substrato à base de casca de pinus enriquecido com hidrolisado de peixe (HP) nâs concentrações dê $0,10,20,30,40^{3}$ e $50 \%$ do volume necessário para atingir a capacidade de retenção de água. $\mathrm{T}=$ testemunha absoluta, $\mathrm{Ti}=$ testemunha inoculada, $\mathrm{HP}=$ hidrolisado de peixe. 
Efeito do hidrolisado de peixe, adicionado ao substrato de cultivo artificialmente infestado, no controle de $C$. spathiphylli. Os sintomas da doença foram visualizados aos 56 dias na testemunha (T) e aos 29 dias na testemunha inoculada (Ti). Nos tratamentos com HP a 10, 20, 30, 40 e 50\% o aparecimento dos sintomas foi aos 30, 57, 52,37 e 30 dias de cultivo, respectivamente. O tempo necessário para atingir 50\% de plantas doentes foi de 82, 86, 112, 103, 109 e 127 dias de cultivo após o transplantio para os tratamentos HP 0, 10, 20, 30, 40 e $50 \%$, respectivamente. A mortalidade total de plantas foi observada na testemunha inoculada e nos tratamentos contendo HP a 10, 20, 30 e $40 \%$ ocorrendo entre 128 e 174 dias após o transplantio das mudas (Figura 1). Os tratamentos com HP apresentaram valores de severidade semelhantes entre as concentrações de 20 a 50\%, com AACPS média de 312,1 $\pm 32,7$, diferindo dos tratamentos Ti e HP a $10 \%$ com AACPS de $366,8 \pm 23,1$ e $351,9 \pm 22,9$, respectivamente (Figura 2). Para o tratamento testemunha não inoculada a área foi de $214,7 \pm 44,9$.

O carbono da biomassa microbiana foi diretamente proporcional à concentração do HP no substrato, variando de $853,9 \mu \mathrm{g} \mathrm{C} \mathrm{g}^{-1}$ solo seco para a testemunha infestada a 4.704,5 $\mu \mathrm{g} \mathrm{C} \mathrm{g}^{-1}$ solo seco para a maior concentração de HP (Figura 3A). Para a hidrólise de FDA os tratamentos diferiram somente em relação à testemunha absoluta $(\mathrm{T})$. Entretanto, houve tendência de aumento com a concentração do HP, com resposta quadrática sendo o ponto de inflexão a 30\% (Figura 3C), com $\mathrm{R}^{2}=0,88$. Para a respiração observa-se resposta linear, mas não houve diferença significativa entre os tratamentos (Figura 3B).

$\mathrm{O} \mathrm{pH}$ e a condutividade elétrica (CE) no plantio apresentaram valores diretamente proporcionais às concentrações de HP incorporadas ao substrato, variando de 4,4 a 6,3 e de 464 a $1484 \mu \mathrm{S}$ $\mathrm{cm}^{-1}$ entre a testemunha e a maior concentração de HP. Aos 182 dias de cultivo os valores de $\mathrm{pH}$ e $\mathrm{CE}$, entre os tratamentos, estabilizaram-se em 4,6 $\pm 0,2$ e $100 \pm 22,10 \mu \mathrm{S} \mathrm{cm}^{-1}$ (Figura 4). O HP aplicado ao substrato de cultivo elevou as concentrações de amônio $\left(\mathrm{N}-\mathrm{NH}_{4}\right)$ de 21,1 para $1720,0 \mathrm{mg} \mathrm{kg}^{-1}$ de substrato seco sendo a resposta diretamente proporcional a concentração $\left(\mathrm{R}^{2}=0,97\right)$; reduziu a amônia $\left(\mathrm{N}-\mathrm{NH}_{3}\right)$ de 350,0 mg kg-1 para zero e manteve os níveis de nitrato $\left(\mathrm{N}-\mathrm{NO}_{3}\right)$ e nitrito $\left(\mathrm{N}-\mathrm{NO}_{2}\right)$ (Figura 5).

\section{DISCUSSÃO DOS RESULTADOS}

O extrato aquoso de hidrolisado de peixe (HP) apresentou, entre as matérias orgânicas testadas, o maior efeito inibitório sobre $C$. spathiphylli (Tabela 2). Por outro lado, os extratos aquosos de torta de mamona, lodo de esgoto e esterco bovino apresentaram efeito conducente ao C. spathiphylli. A variabilidade do efeito dos extratos aquosos de resíduos orgânicos sobre o crescimento micelial de fitopatógenos também foi observada por Koné et al. (18). Esses autores verificaram in vitro que extratos aquosos de esterco de frango, esterco bovino, esterco ovino, algas e casca camarão compostados anaerobicamente por 14 dias, adicionados ao meio BDA na concentração de $15 \%$ (v/v), reduziram o crescimento micelial Alternaria solani, Botrytis cinerea e Phytophthora infestans. Entretanto, a maior efetividade foi para o de esterco ovino com 66, 75 e $100 \%$ de inibição, respectivamente. Santos \& Bettiol (26) testando diferentes concentrações de extratos aquosos de lodo de esgoto adicionados ao meio BDA observaram redução no crescimento micelial de Rhizoctonia solani, Sclerotinia sclerotiorum, Sclerotium rolfsii e Pythium aphanidermatum. Os efeitos dos materiais orgânicos adicionados ao substrato padrão de cultivo sobre o crescimento micelial de C. spathiphylli foram mais evidentes do que quando utilizados os extratos aquosos (Tabela 4). Os tratamentos com HP, CF, TM e CC nas concentrações de 15, 20 e $25 \%(\mathrm{v} / \mathrm{v})$, quando incorporados ao substrato e sem autoclavagem, apresentaram os maiores percentuais de inibição do crescimento micelial em relação a testemunha (Tabela 4).

Diversos trabalhos demonstram o efeito inibitório da quitina, presente na casca de camarão, sobre o crescimento micelial de $A$. solani, $B$. cinerea, $P$. infestans (18) e $R$. solani (27). Todos os resíduos, exceto o HP, na forma de extratos aquosos ou incorporados ao substrato, independentemente das concentrações, quando autoclavados, não inibiram o crescimento micelial do patógeno (Tabelas 2, 3 e 4). A perda de supressividade pelo aquecimento foi observada para Pythium ultimum (9) e B. cinerea (15). A perda de supressividade dos resíduos, resultante da autoclavagem não foi observada para o HP, nas concentrações superiores a $10 \%$, mantendo a inibição total sobre o patógeno (Tabela 4). Segundo Elad \& Shtienberg (15), a perda da supressividade com a autoclavagem não é regra, alguns substratos esterilizados mantêm o efeito. A efetividade dos tratamentos com HP a 15,20 e $25 \%$ na liberação de compostos voláteis inibidores do crescimento micelial do patógeno está diretamente associada à presença dos ácidos graxos voláteis (AGV). Resíduos nitrogenados, líquidos ou sólidos, liberam compostos voláteis de comprovada ação sobre fitopatógenos, sendo que a eficácia do HP pode estar associada a presença AGV principalmente os ácidos acético, fórmico, $n$-butírico e propiônico, pois Abbasi et al. (2) e Abbasi et al. (3), entre outros, demonstraram esses efeitos.

Em resíduos de mamoneira (Ricinus communis), cama de frango e cascas de camarão foram identificados terpenos, cetonas, aldeídos, alcalóides, benzenos e quetonas, todos metabólitos de comprovada ação anti-fúngica. A ação dos compostos voláteis sobre $C$. spathiphylli foi apenas fungistática. Os discos de micélio dos tratamentos com efeito inibitório, quando transferidos para placas contendo apenas BDA, restabeleceram o crescimento micelial. Os metabólitos voláteis são capazes de inibir ou estimular e germinação de esporos e o crescimento micelial de fungos. O tipo e o nível de resposta é dependente das espécies, do estádio de desenvolvimento do fungo, do seu estado nutricional, do tipo e da concentração do volátil presente (21). Os tratamentos com lodo de esgoto e esterco bovino estimularam o desenvolvimento do patógeno.

A baixa efetividade dos extratos aquosos na inibição da germinação de conídios de $C$. spathiphylli (Figura 4) pode estar associada a ausência da microbiota presente nos extratos devido a microfiltração. Elad \& Shtienberg (15) e Koné et al. (18) observaram a presença de bactérias, actinobactérias e leveduras nos extratos aquosos supressivos e a perda da eficácia da supressividade sob microfiltração ou autoclavagem. A ação dos microrganismos presentes em extratos aquosos sobre a germinação de conídios de fungos pode estar associada à produção de sideróforos (14), metabólitos voláteis (21) e ou pelo mecanismo de antibiose (22). Todos os extratos aquosos e os materiais orgânicos, independentemente da autoclavagem, na concentração de 5\% promoveram o crescimento micelial do patógeno (Tabelas $2,3,4$ ). A variabilidade dos resultados sugerem a participação de mais de um mecanismo de ação sobre a inibição do patógeno. A perda de supressividade identificada nos tratamentos autoclavados (Tabelas 2 e 4) e microfiltrados (Tabela 3), evidenciam a importância da microbiota presente nos extratos e nas misturas, sobre a inibição de fitopatógenos $(15,18)$. A inibição total do crescimento micelial do patógeno nos tratamentos com HP a 10, 15, 20 e 25\% autoclavados (Tabela 4) indicam a presença de compostos termoestáveis ou a disponibilidade de novos compostos supressivos liberados pelo aquecimento.

Apesar da agressividade do patógeno (Figuras 1 e 2), semelhante ao observado por Chase \& Poole (8) e Termorshuizen et al. (29), a aplicação do HP apresentou ação supressiva sobre o mesmo. A aplicação de $20 \%$ de HP dobrou o tempo para início do aparecimento dos sintomas da doença e, todas as concentrações do HP aumentaram o tempo para atingir a incidência de $50 \%$ de plantas doentes, em 
relação à testemunha inoculada (Figura 1). O resultados demonstram ação efetiva do resíduo sobre o patógeno porém, apenas com efeito fungistático, diferentemente dos resultados obtidos por Conn et al. (12) onde a aplicação de esterco líquido suíno apresentou efeito fungicida sobre $V$. dahliae. A severidade foi reduzida nas concentrações superiores a $20 \%$ de HP e a concentração de $10 \%$ não diferiu da testemunha inoculada (Figura 2), igualmente aos resultados in vitro (Tabelas $1 \mathrm{e}$ 3 ), onde as menores concentrações promoveram ou não inibiram o crescimento de Cylindrocladium. Abbasi et al. (1) apresentaram resultados semelhantes, reduzindo a severidade de $R$. solani e $P$. aphanidermatum em mudas de rabanete e penino aplicando-se 1-4\% $(\mathrm{p} / \mathrm{p})$ de emulsão de peixe em substrato a base de turfa. Abbasi et al. (2) também verificaram efeito sobre a severidade causada por $S$. scabies em batata aplicando-se ao solo $1 \%$ da emulsão de peixe.

As misturas de substrato apresentaram correlação direta entre as concentrações de HP aplicadas e o carbono da biomassa microbiana no substrato (Figura 3). Os resultados do experimento estão de acordo aos obtidos por Chen et al. (10) que identificaram correlação inversamente proporcional da biomassa microbiana de seis substratos a base de turfa e a incidência no tombamento em mudas de pepino causado por $P$. ultimum.

O aumento do $\mathrm{pH}$ de 4,4 para 6,3 no substrato (Figura 4), foi diretamente proporcional as concentrações de HP. Além de melhorar a absorção de nutrientes o pH distingue-se como um fator abiótico de influência direta na supressividade a $C$. spathiphylli. Chase \& Poole (8) verificaram redução na severidade da doença causada pelo patógeno em cultivos de Spathiphyllum com elevação do $\mathrm{pH}$ do substrato para 6,0 . Termorshuizen et al. (29) confirmaram que a supressividade ao patógeno está correlacionada com o aumento do $\mathrm{pH}$. A condutividade elétrica dos substratos tratados com HP não aingiram o valor de 2,0 dS $\mathrm{m}^{-1}$, limite máximo recomendado para o cultivo das plantas em substratos envasados (17). As concentrações crescentes de amônio $\left(\mathrm{N}-\mathrm{NH}_{4}\right.$ ) (Figura 5) confirmam o HP como resíduo nitrogenado fornecedor de nutrientes solúveis prontamente disponíveis às plantas $(2,3,19,20)$ e com ação promotora de crescimento (1), o que foi comprovado pelo rápido desenvolvimento inicial das mudas de espatifilo após o plantio (dados não apresentados). Lazarovits et al. (20) e Abbasi et al. (2) também verificaram o estímulo no crescimento das plantas com emulsão de peixe (EP). A aplicação de 0,5 a $1 \%$ de emulsão de peixe em solos infestados com $V$. dahliae, utilizado para o controle desta doença, sobre mudas de berinjela, foi suficiente para incrementar em $100 \%$ a biomassa fresca e seca das plantas. As diferentes concentrações e o período de incubação das misturas de substrato e HP foram insuficientes para provocar a morte do patógeno, apresentando apenas efeito fungistático. O efeito supressivo do HP ao $C$. spathiphylli ocorreu no intervalo compreendido do plantio aos 60 dias de cultivo. A partir deste período a incidência do patógeno evoluiu culminando com a morte total das plantas nos tratamentos entre HP 10 a 40\%, bem como na testemunha inoculada (Figura 1). Abbasi et al. (2) verificaram efeito supressivo semelhante incorporando ao solo emulsão de peixe a $1 \%(\mathrm{v} / \mathrm{v})$, com redução significativa da severidade de $V$. dahliae e $S$. scabies em berinjela e batata, respectivamente, porém o efeito perdurou ao período de cultivo. No presente trabalho foi verificado efeito considerável até aos 130 dias do transplante. Entretanto, é importante considerar que, no presente estudo ocorreu uma infestação com alto potencial de inóculo $\left(10^{8}\right.$ conídios $\mathrm{mL}^{-1}$ de substrato). Provavelmente, com menor potencial de inóculo, o HP apresentará melhor resultado.

Apesar de relativamente curta, considerando o ciclo da cultura de 18 meses, a ação inibitória do HP sobre o patógeno foi efetiva enquanto presente no substrato, elevando o carbono da biomassa microbiana (Figura 3), o pH (Figura 4) e o amônio (Figura 5), proporcionalmente às concentrações incorporadas ao substrato. Abbasi et al. (2) descrevem que a aplicação de emulsionados de peixe estimulam o aumento da biomassa microbiana em solos e substratos, incluindo os agentes biocontrole, os quais podem ser particularmente responsáveis pela redução da doença. Abbasi et al. (1) demonstraram que a incorporação de emulsão de peixe ao solo ou em substratos incrementou o número de colônias de bactérias e fungos. El-Tarabily et al. (16) comprovaram que o uso de emulsão de peixe em substratos eleva a população de rizobactérias promotoras de crescimento de plantas em substratos. $\mathrm{O}$ efeito do $\mathrm{pH}$, além a ação direta sobre a inibição de $C$. spathiphylli comprovados por Chase \& Poole (8) e Termorshuizen et al. (29), tem ação na liberação de compostos de comprovada ação fungicida e fungistática presentes em compostos orgânicos nitrogenados líquidos e sólidos, como a amônio e o ácido nitroso $(3,4,11,12,20)$. O amônio, presente em concentrações crescentes com aumento de HP no substrato (Figura 5), pode apresentar-se como uma poderosa ferramenta no controle de fitopatógenos de solo, com dependência direta ao $\mathrm{pH}$, com mecanismos de ação distintos em ambientes alcalinos e ácidos. Em solos ou substratos alcalinos $(\mathrm{pH} \geq 8)$ o amônio converte-

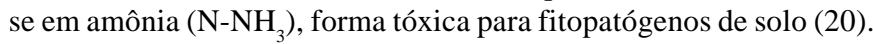
Apesar da efetividade, este mecanismo de ação não ocorreu pois os valores $\mathrm{pH}$ nos substratos decresceram de 6,3 no plantio para 4,4 em média, ao final de 182 dias. Em substratos ácidos, o amônio convertese em nitrito $\left(\mathrm{N}-\mathrm{NO}_{2}\right)$ e este, em ácido nitroso $\left(\mathrm{HNO}_{2}\right)(20)$. Tenuta \& Lazarovits (28) comprovaram ser o $\mathrm{HNO}_{2} 300$ a 500 vezes mais tóxico a microescleródios que $\mathrm{N}-\mathrm{NH}_{3}$.

A efetividade dos ácidos graxos voláteis, presentes em altas concentrações no hidrolisado de peixe comercializado no Brasil (3), sobre o C. spathiphylli é comprovado nas Tabelas 2 e 4, em semelhança aos resultados obtidos por Abbasi et al. (2) sobre $V$. dahliae e $S$. scabies e Abbasi et al. (3) em V. dahliae e P. ultimum.

A perda de supressividade do substrato, após 60 dias, está provavelmente associada às variáveis como: a exaustão do hidrolisado no substrato consumido como nutriente ou lixiviado pela água de irrigação, a redução do pH (Figura 4) e ao alto potencial do inóculo do patógeno no substrato.

Os estudos in vitro e in vivo demonstraram ser o hidrolisado de peixe um promissor agente indutor de supressividade a $C$. spathiphylli (Tabelas 1, 2, 3 e Figuras 1 e 2) agindo sobre o patógeno por meio de diversos mecanismos de supressividade. Porém, a aplicação única de hidrolisado de peixe ao substrato padrão de cultivo, 10 dias antes do plantio e incubado aerobicamente, é insuficiente para a manutenção do efeito supressivo durante todo o ciclo da cultura. Entretanto, o ideal seria testar estas concentrações nas condições de cultivo com a infestação natural do patógeno no substrato ou com menores concentrações do inóculo.

Os resultados experimentais in vitro e o comportamento supressivo no período inicial de cultivo de espatifilo, em concordância aos resultados obtidos por Conn et al. (12), Abbasi et al. (2), Abbasi et al. (3) e Lazarovits et al. (20) comprovam a eficiência do HP na inibição C. spathiphylli. As variáveis abióticas e a microbiota presente desempenham papel importante sobre a inibição do patógeno.

Os resultados obtidos indicam o hidrolisado de peixe como resíduo orgânico promissor ao controle de C. spathiphylli. Há necessidade de novos estudos como objetivo de melhorar a sua persistência no substrato de cultivo.

\section{REFERÊNCIAS BIBLIOGRÁFICAS}

1. Abbasi, P.A.; Conn, K.L.; Lazarovits, G. Suppression of Rhizoctonia and Pythium damping-off of radish and cucumber seedlings by addition of fish emulsion to peat mix or soil. Canadian Journal of Plant Pathology, Ottawa, v. 26, p.177-187, 2004. 
2. Abbasi, P.A.; Conn, K.L.; Lazarovits, G. Effect of fish emulsion used as a preparing soil amendment on verticilllium wilt, scab, and tuber yield of potato. Canadian Journal of Plant Pathology, Ottawa, v. 28, n.4, p. 509-518, 2006.

3. Abbasi, P.A.; Lazarovits, G.; Jabaji-Hare, S. Detection of high concentrations of organic acids in fish emulsion and their role in pathogen or disease suppression. Phytopathology, St Paul, v. 99, n. 3, p. 274-281, 2009

4. Bailey, K.L.; Lazarovits, G. Suppression soil-borne diseases with residue management and organic amendments. Soil \& Tillage Research, Amsterdan, v. 72, p. 169-180, 2003.

5. Bettiol, W.; Pinto, Z.V. Control of Fusarium in chrysanthemum with sewage sludge, biofertilizer, hydrolyzed fish, chitosan and Trichoderma. International Organization for Biological Control of Noxious Animals and Plantas - IOBC. Xth Meeting of the Working Group. Interlaken, Switzerland, September 9-12, 2008. Pág. 48. (Resumos)

6. Bettiol, W.; Ghini, R; Mariano, R.R.L.; Michereff, S.J.; Mattos, L.P.V.; Alvarado, I.C.M.; Pinto, Z.V. Supressividade a fitopatógenos habitantes do solo. In: BETTIOL, W.; MORANDI, M.A.B. (Ed.). Biocontrole de doenças de plantas: uso e perspectivas. Jaguariúna-SP: Embrapa Meio Ambiente, 2009. p. 187-208.

7. Chase, A.R. Compendium of ornamental foliage plant diseases. St Paul: APS Press, 1992. 114p.

8. Chase, A.R.; Poole, R. T. Effects of potting medium $\mathrm{pH}$ and airtemperature on severity of Cylindrocladium root and petiole rot of Spathiphyllum sp. Plant Disease, St Paul, v. 71, p. 509-511, 1987.

9. Chen, W.; Hoitink, A.J.; Schmitthenner, A.F. Factors affecting suppression of Pythium ultimum damping-off in container media amended with composts. Phytopathology, St Paul, v.77, p.755$760,1987$.

10. Chen, W.; Hoitink, A.J.; Schmitthenner, A.F.; Tuovinen, O.H. The role of microbial activity in suppression of damping-off caused by Pythium ultimum. Phytopathology, St Paul, v.78, p.314-322, 1988 .

11. Conn, K.L.; Lazarovits, G. Soil factors influencing the efficacy of liquid swine manure added to soil to kill Verticilllium dahliae. Canadian Journal of Plant Pathology, Ottawa, v. 22, p. 400406. oct. 2000

12. Conn, K.L.; Tenuta, M.; Lazarovits, G. Liquid swine manure can kill Verticillium dahliae microsclerotia in soil by volatile fatty acid, nitrous acid, and ammonia toxicity. Phytopathology, St Paul, v. 95, p. 28-35. 2005.

13. Dick, C.M.; Hutchinson, S.A. Biological activity of volatile fungal metabolites. Nature, v. 211, p. 868, 1966.

14. Diánez, F.; Santos, M.; Boix, A.; De Cara, M.; Trillas, I.; Avilés, M.; Tello, J.C. Grape marc compost tea suppressiveness to plant pathogenic fungi: role of siderophores. Compost Science \& Utilization, Palo Alto, v. 14, p. 48-53, 2006.

15. Elad, Y.; Shtienberg, D. Effect of compost water extracts on grey mould (Botrytis cinerea). Crop Protection, Surrey, v. 13, n. 2, p. 109-114, 1994.

16. El-tarabily, K.A.; Nassar, A.H.; Hardy, G.E.ST.J.; Sivasithamparam, K. Fish emulsion as a food base for rhizobacteria promoting growth of radish (Raphanus sativus L. var. sativus) in a sandy soil. Plant \& Soil, Madison, v.252, p. 397-411, 2003.
17. Kämpf, A.N. Produção comercial de plantas ornamentais. Guaíba (RS): Agropecuária, 1986. 254p.

18. Koné, S.B.; Dionne, A.; Tweddell, R.J.; Antoun, H.; Avis, T.J. Suppressive effect of non-aerated compost teas on foliar fungal pathogens of tomato. Biological Control, v. 52, n. 2, p. 167$173,2010$.

19. Lazarovits, G.; Conn, K.L.; Abbasi, P.A.; Tenuta, M. Undestanding the mode of action of organic soil amendments provides the way for improved management of soilborne plant pathogens. In: International Symposium on Chemical and Non-Chemical Soil and Substrate Disinfestation, 6., 2005. Acta Horticulturae, v. 698, p. 215-224, 2005.

20. Lazarovits, G.; Abbasi, P.A.; Conn, K.L.; Hill, J.E.; Hemmingsen, J.E. Fish emulsion and liquid swine manure: model systems for development of organic amendments as fertilizers with disease suppressive properties. In: BETTIOL, W.; MORANDI, M.A.B. (Ed.). Biocontrole de doenças de plantas: uso e perspectivas. Jaguariúna-SP: Embrapa Meio Ambiente, 2009. p. 49-67.

21. Leite, B.; Sander, P.C.; Sugui, J.A. O papel de compostos voláteis na germinação de esporos fúngicos e na expressão de doenças em plantas. Summa Phytopathologica, Botucatu, v. 21, n. 2, p. $109-116,1995$

22. Martinez, C.; Avis, T.J.; Simard, J.-N.; Labonté, J.; Bélanger, R.R.; Tweddell, R.J. The role of antibiosis in the antagonism of different bacteria towards Helminthosporium solani, the causal agent of potato silver scurf. Phytoprotection, Québec, v. 87, p. 69-75, v. 34, supl., p. 176, 2008. (Resumos).

23. Morandi, M.A.B.; Bettiol, W. Controle biológico de doenças de plantas no Brasil. In: BETTIOL, W.; MORANDI, M.A.B. (Ed.). Biocontrole de doenças de plantas: uso e perspectivas. Jaguariúna-SP: Embrapa Meio Ambiente, 2009. p. 7-14.

24. Norman, D.J.; Yuen, J.M.F.; R.J. Henny. Resistance in Twentytwo cultivars of Spathiphyllum to Cylindrocladium Root Rot. HortTechnology, Alexandria, VA, v. 9, p. 68-69, jan. 1999.

25. Pinto, Z.V.; Bettiol, W.; Morandi, M.A.B. Efeito de casca de camarão, hidrolisado de peixe e quitosana no controle da murcha de Fusarium oxysporum f.sp. chrysanthemi em crisântemo. Tropical Plant Pathology, Brasília, v. 35, n. 1, p. 16-23, Jan/Feb. 2010

26. Santos, I.; Bettiol, W. Effect of sewage sludge on the rot and seedling damping-off of bean plants caused by Sclerotium rolfsii. Crop Protection, Surrey, v. 22, p. 1093-1097, 2003.

27. Sneh, B.; Katan, J.; Henis, Y. Mode of inhibition of Rhizoctonia solani in chitin-amendments soil. Phytopathology, St Paul, v. 61, p. 1113-1117, 1971.

28. Tenuta, M.; G. Lazarovits. Ammonia and nitrous acid from nitrogenous amendments kill the microsclerotia of Verticillium dahliae. Phytopathology, Saint Paul, v.92, p. 255-264, 2002.

29. Termorshuizen, A.J.; Van Rijn, E.; Van Der Gaag, D.J.; Alabouvette, C.; Chen, Y.; Lagerlof, J.; Malandrakis, A.A.; Paplomatas, E.J.; Ramert, B.; Ryckeboer, J.; Steinberg, C.; Zmora-Nahum, S. Suppressiveness of 18 composts against 7 pathosystems: variability in pathogen response. Soil Biology \& Biochemistry, Amsterdan, v. 38, p. 2461-2477, 2006

30. Zmora-nahum, S.; Danon, M.; Hadar, Y.; Chen, Y. Compost curing reduces suppression of plant diseases. Compost Science \& Utilization, Palo Alto, v.14, n. 4, p. 250-256, 2008. 